\title{
Kontribusi Sektor Informal dan Pariwisata dalam Kehidupan Sosial Ekonomi Masyarakat Lokal
}

\author{
Fajrianto
}

The role of tourism industry toward the activity of economy of local community is very important. But, not all tourism objects can contribute to local community optimally especially in the sector that needs formal conditions that difficult to conduct by informal sector of economy. In Indonesia cities, the tourism location is always closely related to informal sector of economy. For this reason, tourism location planning in cities in Indonesia need giving access and space to local community. This planning implies toward increasing the region income.

Kata kunci: angkutan umum, berkelanjutan, sektor informal

$D$ ertumbuhan pariwisata tidak lepas dari pertumbuhan ekonomi dan kesejahteraan berbagai negara, baik Eropa, Amerika, Asia maupun Australia. Paham materialism yang dianut oleh berbagai negara telah mendorong masyarakat untuk hidup lebih produktif karena tolok ukur keberhasilan hidup seseorang diukur secara materi. Dampaknya banyak orang bekerja keras supaya kehidupan ekonomi mereka lebih baik dan dapat menabung sehingga dapat dipergunakan untuk bertamasya. Fenomena ini dapat dilihat bahwa ternyata banyak wisatawan mancanegara yang berkunjung ke Yogyakarta, Bali maupun kota-kota di Indonesia lainnya ternyata belum tentu adalah kelompok the havedi negaranya (KR, 2004). Wisatawan ini ada yang berprofesi sebagai penjaga bar dan restoran, sopir, karyawan, pedagang kecil. Oleh karena itu, tak heran apabila kelompok ini memilih ho- tel-hotel kelas melati, seperti di Pasar Kembang, Prawirotaman, Demangan, sebagai tempat menginap.

Pertumbuhan wisatawan dunia yang sangat potensial ini, telah ditangkap oleh beberapa negara ASEAN seperti Thailand dan Malaysia. Bahkan sektor pariwisata menjadi salah satu sektor unggulannya, karena sektor ini terbukti memberikan sumbangan devisa yang cukup besar bagi negara. Di samping itu sektor ini terbukti sustainable dalam memberikan kontribusi ekonomi, dibandingkan dengan kegiatan ekonomi yang berbasis sumberdaya alam seperti minyak bumi, tambang logam maupun mineral. Malaysia yang terkenal dengan istilah semboyan "Malaysia is Trully ASIA", jumlah kunjungan wisatawannya jauh melebihi Indonesia (lihat Tabel 1). Tercatat sejak krisis ekonomi tahun 1997 hingga 2001, perkembangan kunjungan wisatawan internasional ke Indonesia boleh dikata berjalan di tempat, sedangkan Malaysia sebaliknya, maju pesat. 
Topik: Keterpaduan Sektor Formal dan Informal Perkotaan

Table : Kunjungan Wisatawan Asing di beberapa Negara Asean, 1997 - 2001

\begin{tabular}{|l|c|c|c|c|c|}
\hline Asia Tenggara & 1997 & 1998 & $1999 *)$ & $\left.2000^{*}\right)$ & $\left.2001^{*}\right)$ \\
\hline Indonesia & $5,185,243$ & $4,606,416$ & $6,727,520$ & $5,067,217$ & $5,153,620$ \\
\hline Malaysia & $6,210,921$ & $5,550,748$ & $7,931,149$ & $10,221,582$ & $12,775,073$ \\
\hline Philippines & $2,222,523$ & $2,149,357$ & $2,170,514$ & $1,229,396$ & $1,796,893$ \\
\hline Singapore & $7,197,963$ & $6,242,153$ & $6,958,196$ & $7,691,381$ & $7,518,584$ \\
\hline Thailand & $7,221,345$ & $7,764,930$ & $8,651,260$ & $9,578,826$ & $10,132,509$ \\
\hline
\end{tabular}

Source: Diadopsi dari (Turner \& Witt, 2000) and ") (Waters, 2000, 2001, 2002)

Apabila dibandingkan, sebenarnya kekayaan obyek wisata di Indonesia jauh lebih beragam dan menarik, baik itu wisata alam maupun budaya. Bahkan untuk wisata budaya dan sejarah Malaysia tidak mempunyai peninggalan yang cukup mendunia, sebagaimana Indonesia dengan Borobudur dan Prambanannya. Tetapi mengapa Malaysia jauh lebih unggul dalam kunjungan wisatawan mancanegara dibanding Indonesia, hal ini tidak lain karena faktor manajemen pariwisata yang dilakukan cukup profesional dan integratif, pengemasan dan marketing yang lebih inovatif disamping faktor politik dan keamanan.

\section{Industri Pariwisata, Citra Kota dan Ekonomi Masyarakat}

Lokasi atau tempat dengan ciri dan potensi tertentu di kawasan perkotaan dapat dikembangkan menjadi sumber daya bagi atraksi wisata kota. Lokasi atau tempattempat potensial kota tersebut misainya sungai, taman, tempat bersejarah, museum, gedung teater, auditorium, perguruan tinggi, pusat konvensi, industri dapat menjadi pondasi bagi wisata kota. Tempat-tempat potensial tersebut dapat dikemas dan direncanakan untuk menjadi paket-paket wisata kota. Lingkup kegiatan pariwisata akan mampu mengaitkan berbagai kegiatan ekonomi perkotaan seperti kebutuhan akomodasi, pelayanan makanan, transportasi, dan sovenir. Kegiatan tersebut akan mampu pula mendatangkan serta meningkatkan income, pekerjaan, dan pajak daerah perkotaan (Gunn, 1994).

Dalam mempromosikan wisata, seperti kota-kota di Amerika Serikat, sebagai contoh, senantiasa menghindari citra negatif atau paling tidak justru menonjolkan dan memunculkan aspek budaya dan sejarah yang bercitra positif. Citra negatif kota seperti daerah kumuh, tumpukan sampah, lahan pinggiran yang kotor akan mengurangi keindahan landscape di sepanjang jalan dari pelabuhan udara menuju pusat kota. Kondisi ini didukung oleh berkembangnya sektor informal di kawasan tersebut seperti rumah dan perdagangan di pinggiran jalan. (Dennis, 1995).

Sinergisitas sektor informal dan pariwisata telah terjadi cukup lama dan saling menguntungkan. Di Barbados, India Barat, sektor informal telah menjadi bagian penting dari ekonomi bagi rumah tangga dan industri pariwisata. Sehingga terjadi hubungan komplementer antara sektor formal dan informal melalui kegiatan pariwisata, terutama untuk produksi dan distribusi makanan. Komoditas perdagangan informal 
yang erat dengan kegiatan masyarakat dan pariwisata seperti buah-buahan, sayuran, pakaian, sepatu, dan asesoris seperti ikat pinggang, scarve, dan kaca mata. Kegiatan di sektor informal di Barbados ini secara umum tanpa didasarkan atas peraturan dan tanpa pajak, namun kadang-kadang secara sporadis diberlakukan izin penjualan (Varcin, 2000). Di negara maju perlakuan terhadap para pedagang kaki lima menjadi bagian semi formal dengan diberlakukannya aturan atau perizinan tempat, waktu, dan pembayaran/ pajak. Para pedagang kaki lima di negara maju harus mendapat izin dan membayar sewa tempat untuk jangka waktu tertentu, misal satu tahun. Sehingga aturan tempat di ruang publik dan pemasukan pajak untuk pemerintah menjadi jelas (Council of the City of Charlottetown, 1996). Akhimya, di sekitar kawasan kota dan tempat pariwisata telah ditetapkan tempat-tempat yang dapat diakses atau digunakan bagi PKL untuk berjualan melayani para wisatawan di kawasan perkotaan.

Jumlah sektor informal dari tahun ke tahun semakin bertambah dan telah menjadi bagian dari ekonomi perkotaan. Oleh karena itu, sektor informal perkotaan sangat perlu diperhatikan dan diakui keberadaannya secara struktural ekonomi perkotaan. Bagaimana pun sektor ini terbukti mampu mengurangi pengangguran dan meningkatkan kegiatan ekonomi masyarakat serta memiliki sifat bandel yang sulit untuk dihentikan pertumbuhannya dari waktut ke waktu (Kusumawijaya, 2004). Di negara ketiga seperti Indonesia perlu memadukan keberadaan sektor formal dan informal dalam ekonomi perkotaan (Suparwoko, 2005). Keberadaan sektor informal di perkotaan termasuk obyek wisata kota akan mampu membangkitkan dan memlihara perekonomian rakyat (Prananingtyas, 2001). Memang menjadi kendala bagi pemerintah daerah untuk memperoleh lokasi yang tepat bagi sektor informal perkotaan karena sebagian PKL masih bersifat spontan, fluktuatif dan kompleks (Nesvag, 2000). Dalam kaitan sektor informal atau kegiatan ekonomi masyarakat lokal dengan kegiatan wisata, di Barbados, India Barat, industri pariwisata tidak bisa mengabaikan dukungan sektor informal karena sektor ini telah mampu memasok kebutuhan kegiatan hotel dan restoran seperti komoditas buahbuahan dan sayuran segar, serta daging dan ikan segar (Cutsinger, 2000).

Wall dan Long (1996) mencatat bahwa pertumbuhan wisata di Bali telah membangkitkan berbagai peluang usaha baik masyarakat lokal maupun pendatang di pulau Dewata tersebut. Berbagai usaha yang berkaitan dengan pertumbuhan kepariwisataan Bali termasuk akomodasi, rumah makan, pelayanan pemandu wisata, industri kerajinan, penjualan dan produksi sovenir, pertunjukan kesenian dan budaya serta perdagangan buah dan sayuran di berbagai wilayah terus meningkat. Perkembangan positif di Bali juga dibarengi dengan munculnya aspek negatif, seperti yang disampaikan oleh Wall (1998), bahwa pembangunan secara linier hotel-hotel di sepanjang pantai telah mengurangi akses masyarakat, khususnya masyarakat lokal, untuk memanfaatkan pantai. Sehingga pantai publik menjadi pantai milik privat hotel-hotel sepanjang pantai. Hal ini juga mengurangi akses mayarakat lokal yang mau mengunjung Pure yang berlokasi di pinggir pantai.

Cukier (1996) membahas hubungan antara industri pariwisata Bali dengan pekejjaan. Hasil yang diperoleh menunjukkan, bahwa terdapat kecenderungan masyarakat perdesaan di Bali berpindah ke daerahdaerah tujuan wisata seperti Kuta, Sanur, dan Nusa Dua dengan alasan untuk mencari 
pekerjaan. Sebagai catatan, tahun 1997 semua hotel intemasional di Balia adalah milik orang asing dengan tenaga kerja $83 \%$ adalah orang Bali.Sedangkan hotel menengah $50 \%$ milik orang Indonesia. Adapun kontribusi industri wisata di Bali terhadap masyarakat lokal adalah tumbuhnya home-stay, losmen, rumah makan, galeri seni, dan toko sovenir.

Dalam suatu tahap awal perkembangan obyek wisata di Amosh, Pensilvania Amerika, studi yang dilakukan oleh Hovinen (1995) menyebutkan, bahwa masyarakat lokal mampu berpartisipasi dalam kegiatan industri pariwisata dalam bentuk berbagai produk yang dijual untuk para wisatawan, seperti furnitur, kerajinan, mainan anakanak, selimut, dan berbagai jenis makanan panggang. Studi tersebut memberikan informasi bahwa sejak awal pembangunan pariwisata terdapat akses atau kesempatan bagi masyarakat lokal untuk menjual hasil produksinya di obyek wisata daerah mereka. Sehingga masyarakat lokal bisa merasakan hasil atau manfaat ekonomi dari keberadaan industri pariwisata di daerahnya. Hasil penelitian Gursoy et. al. (2002) menyebutkan bahwa masyarakat lokal sebagai tuan rumah di kawasan pariwisata akan mendukung industri pariwisata mereka dengan didasarkan oleh berbagai faktor yaitu tingkat perhatian, nilai budaya, pemanfaatan sumber daya dasar, dan keuntungan ekonomi yang dapat diperoleh. Di pihak lain, pemerintah daerah dengan mudah menarik pajak dari kegiatan pariwisata untúk kegiatan investasi, pembangunan prasarana wilayah, dan pelayanan masyarakat (Worid Tourism Organization, 1998).

\section{Hotel, Obyek Wisata dan Ekonomi Lokal di Yogyakarta}

Meskipun sektor pariwisata secara nasional mempunyai kontribusi yang cukup signifikan dalam pemasukan devisa nasional, namun seringkali dipertanyakan sejauhmana peran pariwisata dalam memberikan kontribusi terhadap kehidupan sosial ekonomi masyarakat lokal. Pertanyaan ini memang sangat relevan, karena selama ini berbagai fasilitas akomodasi wisata yang berada di Indonesia, khususnya yang bertaraf Internasional, seperti Hyat, Novotel, Aman Group, dsb, dimiliki oleh pemodal asing dan perputaran uang dari wisatawan sebenarnya berada pada jaringan mereka. Masyarakat lokal seringkali hanya sebagai obyek, dimana lokasinya digunakan untuk kegiatan atraksi wisata tetapi tidak mendapatkan keuntungan yang signifikan. Bahkan beberapa kasus di Bali, beberapa fasilitas akomodasi wisata menempati kapling-kapling yang berada di pinggiran pantai, sehingga wilayah pantai yang biasa digunakan masyarakat melakukan upacara adat harus tergeser. Wilayah pantai yang masuk dalam garis sempadan pantai dan merupakan hak masyarakat (publik) telah beralih menjadi milik privat, sehingga masyarakat tidak bisa mengakses lagi. Di samping itu, wisatawan lokal yang tidak berkantong tebal, tidak mampu mengakses atraksi-atraksi wisata yang menarik.

Keberadaan obyek wisata, memang sudah seharusnya memberikan kontribusi terhadap masyarakat lokal dan lingkungannya. Hal ini penting karena masyarakat lokal mempunyai peran penting dalam menyokong keberiangsungan obyek wisata tersebut. Apabila masyarakat lokal menolak keberadaan kegiatan wisata, meskipun secara ekonomi menguntungkan bagi pemerintah daerah, tentu akan terjadi penolakan-penolakan yang dapat mengakibatkan tidak berjalannya kegiatan tersebut secara mulus. Masyarakat lokal juga kelompok yang paling terkena dampak -dari keberadaan suatu obyek wisata. 
Penilaian kontribusi sektor pariwisata terhadap masyarakat, sebenarnya dapat dikelompokkan kedalam kontribusi atau keuntungan secara langsung maupun tidak langsung. Kontribusi secara langsung, seringkali lebih diterjemahkan kedalam sejauh- mana masyarakat lokal menerima keuntungan ekonomi atas keberadaan obyek wisata yang ada di kawasannya. Penilaian ini memang cenderung sempit, karena perhitungannya hanya mendasarkan pada sejauhmana masyarakat lokal menerima keuntungan ekonomi atas keberadaan obyek wisata yang berada di kawasannya.

Kontribusi secara tidak langsung sebenarnya jauh lebih besar nilainya tetapi karena dirasakan secara publik atau masyarakat pada umumnya sehingga kadang-kadang kurang menjadi fokus perhatian masyarakat. Kontribusi ini dapat berupa tangible maupun intangible. Kontribusi tangiblemerupakan manfaat yang dapat dirasakan secara fisik yang dapat berwujud dalam berbagai kualitas fisik seperti meningkatnya kualitas lingkungan, terbukanya akses transportasi kawasan, meningkatnya kualitas prasarana kawasan seperti jaringan listrik, telepon, air, saluran drainassi dan sebagainya. Sedangkan kontribusi intangible merupakan manfaat yang dapat dirasakan masyarakat tetapi tidak selalu harus berupa bersifat fisik, seperti meningkatnya citra kawasan sehingga memberika rasa bangga terhadap kawasannya, meningkatnya keindahan kawasan, meningkatnya rasa aman dan sebagainya.

Perhatian kontribusi tidak langsung, baik yang bersifat tangible maupun intangibel ini seringkali luput dari perhatian masyarakat. Oleh karena itu pemahaman ini perlu disosialisasikan bagi warga masyarakat loka! sehingga penilaián kontribusi sektor pariwisata jangan hanya diterjemahkan secara sempit. Dengan demikian dukungan terhadap keberadaan obyek wisata dapat saling melengkapi.

Pada penelitian Profil Industri Menengah dan Besar di Kabupaten Bantul (Fajriyanto, 2003) menunjukkan, bahwa pertumbuhan industri di Kabupaten Bantul ternyata tidak lepas dari sektor pariwisata. Sebagian besar industri sedang dan besar yang berkembang di Kabupaten Bantul masih terkait dengan kegiatan Pariwisata. Industri mebeuleir, keramik, kulit, handicraft, kain, perak yang menampung jumlah pekerja sangat besar di Kabupaten. Bantul semuanya sangat tergantung dari pertumbuhan pariwisata di Yogyakarta. Oleh karena itu tidak mengherankan ketika kunjungan wisatawan di Yogyakarta menurun, sejumlah perusahaan mengalami penurunan omset penjualan yang sangat signifikan. Kondisi ini menunjukkan bahwa multiflier sektor pariwisata di Yogyakarta sangat besar terhadap perekonomian masyarakat perkotaan maupun wilayah hinterlanchya. Pertumbuhan Industri di. Kabupaten Bantulpun temyata teraglomerasi di kecamatan Kasihan dan Sewon yang merupakan jalur Pariwisatà di Jogjakarta Selatan. Bahkan keberadaaan sentra industri keramik Kasongan telah menjadi obyek wisata tersendiri yang mempunyai nilai khas.

Berdasarkan kondisi tersebut beberapa isu yang ,perlu diperhatikan dalam meningkatkan kontribusi sektor pariwisata, khususnya pariwisata kota terhadap kehidupan sosial ekonomi masyarakat lokal adalah peningkatan diversifikasi dan intensifikasi wisata kota, integrasi dalam perencanaan pariwisata kota, sistem manajemen sektor informal dan manajeman pajak yang transparan. 


\section{Diversifikasi dan Intensifikasi Wisata Kota}

Lama kunjungan wisatawan di Yogyakarta relatif masih rendah, yaitu ratarata kurang dari 3 hari. Kondisi ini tidak lepas dari keterbatasan obyek-obyek wisata di Yogyakarta. Sampai sekarang Yogyakarta masih mengandalkan Candi Borobudur dan Prambanan sebagai "icon" daya tarik wisatawan, sementara obyek-obyek wisata potensial lainnya kurang digarap secara serius. Persoalan sebenarnya adalah kurangnya pengemasan obyek wisata sedemikian rupa sehingga mempunyai karakteristik yang cukup unik dengan manajemen marketing profesional.

Yogyakarta sebagai kota budaya dan kota perjuangan, menyimpan berbagai peninggalan sejarah yang belum digali secara optimal. Salah satu potensiyang belum tergarap adalah wisata heritage buildings (bangunan warisan) dimana jumlahnya masih cukup banyak. Beberapa bangunan masih terawat dengan baik, seperti di kawasan Beteng Vredeburg, Kantor Pos dan Bank Indonesia tetapi pada banyak kawasan lain kondisinya cukup memprihatinkan. Bahkan di kawasan Tugu dan Jl. AM. Sangaji yang menyimpan bangunan warisan yang cukup banyak, dan merupakan kawasan perumahan peninggalan Belanda, serta mempunyai nilai sejarah yang cukup tinggi, kondisinya cukup memprihatinkan (Fajriyanto; 1994). Beberapa bangunan sudah dirobohkan pemiliknya dan digantikan dengan bangunan baru, padahal apabila kawasan ini dikembangkan sebagai obyek wisata akan menambahkan keberagaman obyek wisata di Yogyakarta. Kawasan inipun dapat dikembangkan sebagai wisata souvenir dan handicraft. Pada sore dan malam hari kawasan dapat dikembangkan dengan kegiatan restoran terbuka yang memanfaatkan ruang-ruang terbuka di depan bangunan warisan yang umumnya mempunyai halaman yang cukup luas sehingga kawasan menjadi hidup.

Berbagai wisata kota di Yogyakarta sebenarnya telah mempunyai keragaman, seperti wisata belanja, wisata sejarah, wisata alam, museum, upacara adat dan sebagainya, tetapi diversifikasi obyek wisata di Yogyakarta sebenarnya masih terbuka luas. Di samping diversifikasi wisata, aspek yang tidak kalah pentingnya adalah intensifikasi obyek wisata sehingga obyek wisata yang ada mempunyai kualitas yang layak saji dan tidak terkesan asal-asalan. Apabila diversifikasi dan intensifikasi ini dilakukan, maka dapat menambah lama kunjungan wisatawan, yang berarti semakin banyak uang yang dibelanjakan. Akibatnya akan semakin banyak kontribusi sektor ini dalam menyumbangkan peningkatan kegiatan ekonomi masyarakat.

\section{Peningkatan Integrasi dalam Perencanaan Pariwisata Kota}

Beberapa perencanaan pembangunan di Indonesia masih cenderung dilakukan secara sektoral dan tidak dilakukan secara terintegrasi. Antar sektor masih cenderung berjalan masing-masing dan kalaupun dilakukan koordinasi, masih bersifat formalitas dan tidak menyentuh hal-hal yang substansial. Akibatnya sering terjadi overlaping dalam penyelesaian masalah atau kegiatan dan mungkin justru tidak ada yang menyelesaikan.

Pariwisata sebagai sektor yang melibatkan banyaksektorlain, membutuhkan perencanaan yang terintegrasi dengan sektor-sektor lain, sehingga melibatkan banyak dinas-dinas yang terlibat. Beberapa dinas yang berhubungan dengan peningkatan integrasi perencanaan pariwisata adalah dinas prasarana wilayah, 
pekerjaan umum, kebudayaan, Bappeda, tata kota, DLLAJR, dan dipenda. Hal ini perlu dilakukan untuk mengembangkan secara matang sebuah obyek wisata. Dengan kata lain, perlu dukungan infrastrutur yang memadai, kesesuaian dengan rencana kota, sistem jaringan transportasi yang integrasi, kebutuhan sarana transportasi, sistem marketing, dan sebagainya.

Apabila perencanaan pariwișata dilakukan secara terpadu dengan melibatkan berbagai dinas terkait, maka pengembangan pariwisata akan lebih terarah dan mempunyai tahapan yang jelas. $\mathrm{Di}$ samping itu sistem pendanaannya pun dapat saling komplementer. Di samping itu keterlibatan swasta dan masyarakat dibutuhkan sehingga perencanaan tidak hanya bersifat top down tetapi mampu mengakomodasi tuntutan dan kebutuhan masyarakat (bottom up).

\section{Sistem Manajemen Sektor Informal}

Sektor informal merupakan suatu fenomena yang tidak mungkin dihindari terhadap keberadaan obyek wisata. Munculnya sebuah obyek wisata tentu akan diikuti dengan munculnya sektor informal, baik yang terkait langsung maupun tidak langsung. Munculnya pedagang kaki lima dan asongan adalah fenomena yang selalu mengikuti keberadaan obyek wisata. Kondisi ini merupakan gejala spesifik di negara-negara miskin dan berkembang seperti Indonesia, akibat terbatasnya pekerjaan-pekerjaan formal dan besarnya tingkat pengangguran. Justru kondisi ini menunjukkan betapa suatu obyek wisata mempunyai kontribusi secara langsung terhadap kesempatan berusaha bagi masyarakat. Oleh karena itu yang menjadi permasalahan bukanlah keberadaan sektor informal, seperti pedagang kaki lima dan asongan, tetapi bagaimana mengelola keberadaanya sehingga mempunyai kontribusi positif terhadap obyek wisata.

Pengelolaan sektor informal kota memang bukan pekerjaan mudah, namun pengakuan terhadap keberadaannya akan membuka peluang dalam berfikir bagaimana mengintegrasikan keberadaannya dalam sistem perencanaan pariwisata, sehingga terjadi hubungan simbiosis mutualisme. Di Singapura dan Malaysia, pedagang informal tercatat dalam sistem registrasi, sehingga memudahkan pemerintah kota dalam melakukan pengelolaan. Pembinaan dan pengontrolan dapat dilakukan karena datadata atas keberadaannya, baik pemilik, pekerja, jenis dagangan, waktu operasi, volume, dan omset dagangannya tersimpan dalam data baseyang memudahkan dalam pemantauan.

Pada banyak kota di Indonesia, manajemen sektor informal belum dilakukan secara baik dan umumnya masih parsial dalam menajemen pengembangan pariwisata. Padahal sektor informal perkotaan menjadi tumpuan kehidupan sebagian besar masyarakat sejak terjadinya krisis ekonomi yang dimulai tahun 1997 (Saroso, 2004). Beberapa kota seperti Yogyakarta dan Sleman memang telah memiliki Peraturan Daerah (Perda) yang mengatur keberadaan PKL ini, tetapi manajemen yang lebih mengarah pada peningkatan PKL sebagai aset wisata belum terjamah.

Harus diakui bahwa Malioboro tanpa PKL ibarat sayuran tanpa garam yang rasanya terasa hambar. Oleh karena itu, yang diperlukan bukan menghilangkan $P K L$, tetapi bagaimana PKL tersebut terintegrasi dalam sistem wisata belanja yang menarik, unik, menyenangkan, tetap menjaga kenyamanan wisatawan dalam berbelanja, 
sirkulasi yang nyaman dan tercipta rasa aman bagi wisatawan.

Keberadaan PKL yang terlalu banyak, mengakibatkan overload sehingga tidak sesuai dengan daya tampungnya. Kondisi ini akan berakibat justru melemahkān citra kawasan, sehingga wisatawan merasa tidak nyaman, menyenangkan dan kurangnya rasa aman. Di samping itu, pedagang pun akan terjadi persaingan yang tidak sehat, sehingga dapat saling merugikan.

Berdasarkan kondisi tersebut, maka manajemen sektor informal kota diperlukan sehingga kota mempunyai sistem yang baku dalam pengelolaan sektor informal, baik meliputi pembinaan, pengelolaan dan pengarahan lokasi-lokasi yang diizinkan, jenis dagangan, shelteryang digunakan dan sebagainya. Kondisi ini akan lebih menjamin keberadaan PKL sebagai sebuah aset wisata yang unik.

\section{Manajemen Pajak Pariwisata}

Bali merupakan propinsi yang pemasukan PAD terbesarnya dari sektor pariwisata, tetapi pajak Hotel dan Restoran ternyata baru $33 \%$ yang berhasil dipungut, berarti sebagian besar wajib pajak $(67 \%)$ belum menyerahkan pajaknya atau terjadi penggelapan (Bali Post, 2004). Kondisi ini menunjukkan bahwa manajemen pajak sektor pariwisata masih memprihatinkan, belum lagi bagaimana pengelolaan pajak yang berhasil dihimpun.

Pada banyak negara maju, sektor pajak merupakan tumpuan dalam pengelolaan kota dan daerah, sehingga manajemen pajak menjadi salah satu fokus yang mampu mendorong pertumbuhan kota. Manajemen pajak bukan sekadar bagaimana mengambil pajak dari masyarakat; tetapi termasuk bagaimana mengelolanya sehingga sesuai sasaran dengan cara yang efisien dan efektif.

Transparansi merupakan salah satu kunci keberhasilan dalam manajemen pajak, karena melalui transparansi masyarakat akan mengetahui seberapa besar pajak yang mampu dikelola kota, bagaimana didistribusikan dalam pembangunan, kapan, berapa besarnya, dan siapa penanggungjawabnya.

Masyarakat juga dapat mengakses untuk mengetahuj, apakah pajak yang diserahkan ke petugas lapangan sudah sampai ke kas pemerintah kota dan dapat mengakses untuk apa pajak tersebut digunakan. Oleh karena itu dibutuhkan sistem informasi yang memungkinkan masyarakat mengetahui pengelolaan dan pemanfaatan pajak yang dipungut. Transparansi ini sangat dibutuhkan, sehingga masyarakat merasa yakin, bahwa pajaknya memang digunakan untuk pengelolaan kota dan kemajuan masyarakat sehingga tumbuh rasa memiliki.

\section{Penutup}

Peran industri pariwisata terhadap kegiatan sosial ekonomi masyarakat lokal sangat penting. Namun, tidak semua obyek pariwisata telah mampu memberikan kontribusi terhadap masyarakat lokal dengan optimal, terutama perhotelan yang memiliki berbagai persyaratan resmi sehingga sulit ditembus oleh sektor ekonomi informal. Di kawasan perkotaan Indonesia, munculnya obyek wisata akan selalu diikuti oleh sektor ekonomi informal, oleh karena itu perencanaan obyek wisata kota sejak awal perlu memberikan akses bagi masyarakat lokal untuk bisa menempati (sewa) sejumlah tempat atau ruangan bagi mereka untuk berjualan. Dalam proses perencanaan obyek wisata, sektor informal 
harus menjadi bagian dari pemangku kepentingan (stakeholders) yang perlu dilibatkan dalam pengambilan keputusan yang berkaitan dengan kegiatan sektor informal dalam bagian obyek wisata secara terpadu. Kehadiran sektor informal dalam obyek wisata mampu memberikan alternatif pelayanan bagi wisatawan untuk memperoleh barang dan jasa yang relatif terjangkau, karena tidak semua pengunjung obyek wisata perkotaan adalah masyarakat kaya. Kehadiran sektor ekonomi informal di kawasan pariwisata perkotaan juga mampu memberikan peningkatan income daerah kota melalui sewa tempat maupun retribusi. Akses masyarakat lokal sebagai sektor ekonomi informal sangat perlu diperhatikan untuk memberikan kestabilan sosial ekonomi masyarakat disekitar obyek pariwisata yang pada akhirnya akan mendukung income daerah dan keberlanjutan industri kepariwis̀ataan di perkotaan. Pengembangan PKL di kawasan perkotaan sebagai obyek wisata sangat perlu dikembangkan, selain untuk meningkatkan ekonomi masyarakat juga untuk mengurangi pengangguran. Pendapatan pemerintah daerah melalui retribusi atau pajak perlu dikelola dengan transparan. Dengan transparansi pengelolaan retribusi/pajak diharapkan penggunaannya akan memberikan manfaat langsung (misal kenyamanan dan keamanan) bagi sektor informal untuk melanjutkan usahanya di dalam obyek pariwisatá. Sebagai implikasinya, setiap obyek wisata perlu menyediakan ruang atau lahan yang dapat disewa bagi masyarakat lokal terutama sektor informal (PKL) untuk melakukan usaha seperti penjualan hasil kerajinan/sovenir, pelayanan makan minum, parkir, dsb. yang dijamin keberadaanya oleh pemerintah daerah dan pengelola obyek wisata yang bersangkutan.

\section{Daftar Pustaka}

Bali Post, 24 Maret 2004.

Council of the City of Charlottetown. (1996). Street Vendors Bylaw. Charlottetown: Council of the City of Charlottetown.

Cukier, J. (1996). Tourism employment in Bali: trends and implications. In T. Hinch (Ed.), Tourism and Indigenous People (pp. 49-75). London, UK: Intemational Thomson Business Press.

Cutsinger, L. E. (2000). Tips of the Trade: Street Vendors and the State in Barbados, West Indies. International Journal of Sociology and Social Policy, 21(3/4).

Dennis, R. J. (1995). Promoting tourism in US cities. Tourism Management, 16(3), 175-187.

Fajriyanto, Hari Purnomo, dkk, 2003,Profil Industri Besar dan Menengah di Kabupaten Bantul, Lempaga Penelitian UII.

Fajriyanto dan Hanif Budiman,2004, Konflik Ruang di Jalan AM. Sangaji dan Mangkubumi Yogyakarta, Lempaga Penelitian UII.

Gunn, C., A. (1994). Tourism Planning; Basics, Concepts, Cases. Washington, DC, USA: Taylor \& Francis.

Gursoy, D., Jurowski, C., \& Uysal, M. (2002). Resident Attitudes: A Structural Modeling Approach. Annals of Tourism Research, 29(1), 79-100.

Hovinen, G. R. (1995). Heritage issues in urban tourism: an assessment of new 
Topik: Keterpaduan Sektor Formal dan Informal Perkotaan

trends in Lancaster County. Tourism management, 16(5), 381-388.

Kedaulatan Rakyat, 15 September 2004

Kusumawijaya. (2004). Membangun Kota Informal. Retrieved2 Desember, 2004, from http:/www.urbanpoor.or.id/ web_lama/rtrw/informalitas.htm

Nesvag, S. (2000). Street trading from Apartheid to Post-Apartheid: More birds in the cornfield? Intemational Joumal of Sociology and Social Policy, 21(3/4).

Prananingtyas, P. (2001). Pembaharuang Peraturan Perundang-undangan Mngenai Usaha Kecil dan Menengah di Indonesia. Semarang: Unpublished.

Saroso, Wicaksono Menyoroti Sektor Informal Perkotaan, Info URDI Vol 12, 2004.

Suparwoko. (2005). Pola Hubungan Sektor Formal Informal di Perkotaan: studi kasus penataan PKL di Sleman, DI Yogyakarta. Paper presented at the Pembangunan Lingkungan Perkotaan di Indonesia, FALTL - Universitas Trisakti, Kampus A Gedung K, Lantai 7, Jl. Kyai Tapa No 1, Grogol - Jakarta 11440.

Turner, L. W., \& Witt, S. F. (2000). Asia Pacific Tourism Forecast 2000-2004. UK: Travel \& Tourism Intelligence.
Varcin, R. (2000). "Competition in the Informal Sector of the Economy:the Case of Market Traders in Turkey." International Joumal of Sociology and Social Policy, 21(3-4).

Wall, G. (1998). Landscape Resources, Tourism and Landscape Change in Bali, Indonesia. In G. Ringer (Ed.), Destinations: Cultural Landscape of Tourism (pp. 51-62). London: Routledge.

Wall, G., \& Long, V. (1996). Balinese Homestays: an indigenous response to tourism opportunities. In T. Hinch (Ed.), Tourism and Indigenous People (pp. 27-48). London: International Thomson Business Press.

Waters, S. R. (2000). Travel Industry World 2000 Yearbook: The Big Picture. New York: Travel Industry Publishing Company.

Waters, S. R. (2001). Travel Industry World 2001 Yearbook: The Big Picture. New York: Travel Industry Publishing Company.

Waters, S. R. (2002). Travel Industry World 2002 Year Book: The Big Picture. New York: Travel Industry Publishing Company.

World Tourism Organization. (1998). Tourism taxation: Striking a fair deal. Journal of Travel Research, 31(1), 42-49. 